\title{
More Often than Once a Day
}

National Cancer Institute

\section{Source}

National Cancer Institute. More Often than Once a Day. NCI Thesaurus. Code C129570.

An indication that something is scheduled, or occurs, more than once a day. 